\title{
Kapasitasi Spermatozoa Sapi Peranakan Ongole dalam Berbagai Formulasi Pengencer Air Kelapa Selama Simpan Dingin
}

\author{
Dedi Muhammad $^{1 *}$, Nurul Isnaini ${ }^{1}$, Kuswati $^{1}$, Aulia Puspita Anugra Yekti ${ }^{1}$, Muchmad \\ Luthfi $^{2}$, Lukman Affandhy Sunarto ${ }^{2}$, Trinil Susilawati ${ }^{*}$ \\ ${ }^{1}$ Fakultas Peternakan Universitas Brawijaya Malang \\ Jl. Veteran, Lowokwaru, Malang, Jawa Timur 65145 \\ ${ }^{2}$ Loka Penelitian Sapi Potong Grati \\ J1. Pahlawan 2, Grati, Pasuruan, Jawa Timur 67184 \\ *Email korespondensi: dedi.pendidik@gmail.com; trinil_susilawati@yahoo.com
}

(Diterima: 19-12-2018; disetujui 10-1-2019)

\begin{abstract}
ABSTRAK
Pengencer dasar air kelapa merupakan solusi dari sulit dan mahalnya harga pengadaan bahan baku pembuatan pengencer. Tujuan dari penelitian ini adalah untuk mengetahui kapasitasi spermatozoa sapi Peranakan Ongole dalam berbagai formulasi pengencer air kelapa selama simpan dingin pada suhu $4-5^{\circ} \mathrm{C}$. Metodologi yang digunakan adalah eksperimantal laboratorium menggunakan rancangan acak kelompok (RAK). Terdapat tiga perlakuan yaitu, $\mathrm{P} 1=$ Pengencer air kelapa $+20 \%$ kuning telur, $\mathrm{P} 2=$ Pengencer air kelapa $+20 \%$ kuning telur $+0,4 \%$ putih telur + fruktosa $1000 \mathrm{mg} / \mathrm{l}$. P3 $=$ Pengencer air kelapa $+20 \%$ kuning telur $+0,4 \%$ putih telur + fruktosa $2000 \mathrm{mg} / \mathrm{l}$, dengan 10 ulangan. Hasil menunjukkan bahwa tidak terdapat perbedaan yang signifikan pada persentase spermatozoa belum kapasitasi, terkapasitasi dan telah rekasi akrosom antara perlakuan formulasi pengencer air kelapa yang berbeda (P1, P2, P3) selama peyimpana suhu $2-5^{\circ} \mathrm{C}$. Pengencer berbasis air kelapa mampu mempertahankan kualitas akrosom diatas $50 \%$ penyimpanan hari ke lima.
\end{abstract}

Kata kunci : air kelapa, kapasitasi, reaksi akrosom, semen cair

\begin{abstract}
Coconut water extender is the solution to the difficulty and high cots of semen diluents. The objective of this study were to examine the capacitation of Ongole Crossbreed sperm in various formulations of coconut water extender during storage in $4-5{ }^{\circ} \mathrm{C}$. The study method used laboratory experimental. The experimental design was Randomized Completely Block Design and the data were analyzed by Analyze of Variance. There are three treatments in this study $(\mathrm{P} 1=$ Coconut Water $+20 \%$ of yolk, $\mathrm{P} 2=$ Coconut Water $+20 \%$ of yolk $+0,4 \%$ white egg + fructose $1 \mathrm{mg} / \mathrm{ml}$, dan $\mathrm{P} 3=$ Coconut Water $+20 \%$ of yolk $+0,4 \%$ white egg + fructose $2 \mathrm{mg} / \mathrm{ml}$ ) and ten replications of each treatment. There were not significant differences in percentage of sperm uncapacitation, sperm capacitaion and sperm acrosom reaction between various formulations of coconut water diluents during chilled storage at $4-5^{\circ} \mathrm{C}$. Coconut water diluents are able to maintain quality of sperm acrosom up to day $5^{\text {th }}$ with values above $50 \%$.
\end{abstract}

Keywords: acrosom reaction, capacitation, coconut water, liquid semen

\section{PENDAHULUAN}

Metode penyimpanan semen dalam bentuk semen cair telah terbukti mampu menguragi tingkat kerusakan membran spemratozoa. Semen cair dibuat dengan menambahkan pengencer kemudian disimpan pada suhu $2-4{ }^{\circ} \mathrm{C}$ (Susilawati et al., 2018). Bahan pengencer yang ditambah bertujuan untuk memenuhi nutrisi dan menyediakan lingkungan yang sesuai bagi spermatozoa. Disamping itu pengencer juga harus memiliki kemampuan untuk melindungi spermatozoa dari kerusakan akibat suhu, dibuat 
dari bahan-bahan lokal yang mudah didapatkan, dan harganya tidak mahal (Susilawati, 2011).

Air kelapa sebagai bahan lokal yang mudah didapatkan di lingkungan sekitar dapat dijadikan sebagai pengencer semen alternatif. Kandungan beberapa karbohidrat, mineral, serta zat-zat lain dalam air kelapa mampu memenuhi kebutuhan spermatozoa. Vigliar, Sdepanian, and Neto (2006) menyatakan bahwa air kelapa mengandung unsur karbon berupa karbohidrat sederhana, seperti: sukrosa, glukosa, dan fruktosa. Yong et al. (2009) menambahkan bahwa kandungan yang terkandung di dalam air kelapa muda yaitu air $94,180 \mathrm{~g} / 100 \mathrm{~g}$, lipid 0,073 $\mathrm{g} / 100 \mathrm{~g}$, protein $0,120 \mathrm{~g} / 100 \mathrm{~g}, \mathrm{pH} 4,7$ dan mengandung beberapa ion yaitu $\mathrm{Na}, \mathrm{Zn}, \mathrm{Fe}, \mathrm{P}$, $\mathrm{Ca}, \mathrm{Mn}, \mathrm{Cu}$ serta beberapa asam amino yaitu arginin, metionin, alanin, lisin, aspartat fenilalanin, glisin, serin, glutamat, prolin, histidin, isoleusin, treonin, valin dan leusin.

Penambahan bahan pengencer selama proses pengenceran semen dapat menyebabkan turunnya kadar zat-zat yang terkandung dalam plasma semen, misalnya kadar asam amino, lemak dan ion-ion yang dapat mempengaruhi keseimbangan osmolaritas yang dapat mempengaruhi motilitas dan kapasitasi spermatozoa (Adnani, Bebas, dan Budiasa, 2012). Sumber energi berupa fruktosa serta zat makromolekul berupa protein ditambahkan dalam pengencer air kelapa diharapkan mampu menggantikan beberapa zat yang telah hilang dari plasma semen akibat proses pengenceran sehingga mempu mempertahankan kehidupan spermatozoa.

Hasil Audia et al. (2017); Mugiyati et al. (2017); Salim et al. (2018) menunjukkan bahwa penggunaan pengencer air kelapa dengan varietas yang berbeda sebagai pengencer semen kambing boer mampu mempertahankan kualitas spermatozoa yang masih baik hingga hari ke 2 pada penyimpanan suhu $4-5^{\circ} \mathrm{C}$. Daramola et al. (2016) menambahkan bahwa pengencer air kelapa memiliki kemampuan menjaga intergitas akrosom spermatozoa rusa dengan baik. Hal tersebut memungkinkan spermatozoa terjaga dari kapasitasi dan reaksi akrosom.

Pengencer dengan bahan dasar air kelapa dengan penambahan kuning telur sebagai bahan krioprotektan, fruktosa sebagai substrat energi tambahan dan putih telur sebagai makromolekul diharapkan dapat mempertahankan kualitas dan status belum kapasitasi spermatozoa seoptimal mungkin. Berdasarkan uraian tersebut perlu dilakukan penelitian tentang kapasitasi spermatozoa sapi PO (Peranakan Ongole) dalam berbagai formulasi pengencer air kelapa selama simpan dingin.

\section{METODE PENELITIAN}

\section{Lokasi dan Waktu Penelitian}

Penelitian dilaksanakan di Laboratorium Loka Penetilian Sapi Potong Grati Pasuruan dan Laboratorium Biomedik Fakultas Kedokteran Universitas Brawijaya pada bulan April 2018.

\section{Semen Sapi PO}

Semen sapi PO yang digunakan memiliki kriteria motilitas massa minimal 2+, motilitas individu minimal $70 \%$. Frekuensi penampungan paling banyak dua kali per minggu. Semen ditampung menggunakan teknik vagina buatan.

\section{Pengencer Air Kelapa}

Pengencer air kelapa dibuat dari bahan dasar air kelapa yang diambil dari jenis kelapa hijau (Cocos nucifera) dengan usia buah 5 sampai 8 bulan. Sebelum air kelapa digunakan, terlebih dahulu disaring menggunakan kertas saring halus kemudian dipanaskan dengan suhu $57^{\circ} \mathrm{C}$ selama 25 menit. Pamanasan bertujuan untuk menonaktifkan enzim yang ada pada air kelapa. Setelah itu ditambahkan $\mathrm{NaHCO} 31 \mathrm{mg} / \mathrm{ml}$ sebagai buffer, antibiotik streptomycin sulfate 1 $\mathrm{mg} / \mathrm{ml}$ dan penicillin $1 \mathrm{mg} / \mathrm{ml}, 20 \%$ kuning telur ayam ras, dan sebagai perlakuan yaitu putih telur ayam $0,4 \%$, fruktosa 10 dan $20 \mathrm{mg} / \mathrm{ml}$.

\section{Rancangan Penelitian}

Penelitian ini menggunaan Rancangan Acak Kelompok (RAK) dengan 3 perlakuan dan setiap perlakukan diulang 10 ulangan. Pengelompokan dilakukan berdasarkan waktu penampungan. Perlakuan terdiri atas: Perlakuan pertama $(\mathrm{P} 1)=$ Pengencer air kelapa $+20 \%$ kuning telur ayam ras. Perlakuan kedua $(\mathrm{P} 2)=$ Pengencer air kelapa $+20 \%$ kuning telur ayar ras $+0,4 \%$ putih telur + fruktosa $1000 \mathrm{mg} / \mathrm{l}$. Dan perlakuan ketiga $(\mathrm{P} 3)=$ Pengencer air kelapa + $20 \%$ kuning telur $+0,4 \%$ putih telur + fruktosa $2000 \mathrm{mg} / \mathrm{l}$.

\section{Pemeriksaan Status Akrosom (CTC)}

Metode pemeriksaan status akrosom menggunakan mikroskop epiflouresence dengan pewarnaan Chlortetracycline (CTC). Prosedur pewarnaan CTC yang digunakan dalam pemeriksaan status akrosom dilakukan dengan cara yaitu $45 \quad \mu l$ semen yang diperiksa dimasukkan ke dalam ependrof kapasitas 1,5 ml, tambahkan $45 \mu 1$ larutan pewarna CTC kemudian goyang - goyang selama 2-3 menit, setelah itu 
ditambahkan $8 \mu$ CTC Fixative dan digoyang lagi selama 1 menit. Dari larutan tersebut diambil $10 \mu 1$ kemudian ditempatkan pada object glass kemudian ditambahkan $10 \quad \mu 1$ larutan 1,4diazabicyclooctane (DABCO) kemudian dicampur rata secara hati-hati, setelah itu ditutup dengan cover glass. Tahap terakhir ditutup dengan tisu yang tebal kemudian ditekan-tekan secara hati-hati, tepi cover glass ditutup menggunakan cutex untuk melindungi preparat dari kerusakan (Morado et al., 2015).

\section{Analisis Data}

Data yang diperoleh dianalisa menggunakan analisis ragam (ANOVA) dengan RAK (Rancangan Acak Kelompok) kemudian dilakukan pengujian lanjut menggunakan Duncan's Multiple Range Test (Uji Jarak Berganda Duncan).

\section{HASIL DAN PEMBAHASAN}

\section{Kualitas Semen Sapi PO}

Pemeriksaan semen sapi PO sebelum diencerkan meliputi pemeriksaan makroskopis dan mikroskopis. Pemeriksaan makroskopis meliputi pemeriksaan $\mathrm{pH}$, warna, volume, dan konsistensi spermatozoa. Pemeriksaan mikroskopis terdiri dari pemeriksaan motilitas massa, motilitas individu, abnormalitas, viabilitas, konsentrasi, status akrosom spermatozoa. Rata-rata dan simpangan baku kualitas semen sapi PO sebelum dilakukan pengenceran dapat dilihat pada Tabel 1 .

Rata-rata hasil pengamatan volume semen dari sapi PO yang digunakan untuk penelitian adalah $4,67 \pm 0,58 \mathrm{ml}$.

Tabel 1. Rata-rata kualitas semen sapi PO sebelum pengenceran

\begin{tabular}{lc}
\hline Parameter & Rata-rata \pm simpang baku \\
\hline Makroskopis & \\
Volume per ejakulat (ml) & $4,67 \pm 0,58$ \\
Warna & Putih susu \\
pH & $6,47 \pm 0,12$ \\
Konsistensi & kental \\
\hline Mikroskopis & \\
Motilitas Massa & ++ \\
Motilitas Individu (\%) & $71,67 \pm 2,89$ \\
Viabilitas (\%) & $91,39 \pm 2,38$ \\
Abnormalitas (\%) & $2,81 \pm 0,80$ \\
Konsentrasi (juta/ml) & $1260,00 \pm 222,71$ \\
Spermatozoa Belum Kapasitasi (\%) & $86,40 \pm 1,97$ \\
Spermatozoa Terkapasitasi (\%) & $9,41 \pm 1,35$ \\
Spermatozoa Telah Reaksi Akrosom (\%) & $4,19 \pm 1,02$ \\
\hline
\end{tabular}

Hasil tersebut termasuk rendah jika dibandingkan dengan pernyataan Garner and Hafez (2008) bahwa volume semen sapi hasil penampungan berkisar antara 5-8 ml. Adapun $\mathrm{pH}$ semen rata-rata $6,47 \pm 0,12$. Hasil tersebut memperlihatkan bahwa $\mathrm{pH}$ semen yang digunakan untuk penelitian adalah normal. Ax et al., (2008) menjelaskan bahwa $\mathrm{pH}$ semen sapi berkisar antara 6,4 sampai 7,8.

Rata-rata persentase motilitas massa semen sapi PO yang digunakan untuk penelitian adalah $2+$. Persyaratan motilitas massa agar semen dapat diproses minimal 2+ (Ducha et al., 2013). Rataan motilitas individu semen segar sapi PO yang digunakan adalah 71,67 $\pm 2,89 \%$. Muhammad et al. (2016) menyatakan bahwa syarat minimal nialai motilitas semen untuk diencerkan adalah $70 \%$. Nilai konsentrasi spermatozoa semen sapi

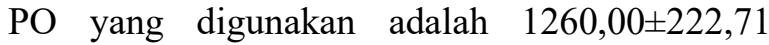
juta/ml. Garner and Hafez (2008) bahwa konsentrasi semen sapi bervariasi dari 1.0001.800 juta spermatozoa setiap mililiter atau 800 2.000 juta spermatozoa setiap mililiter. Rata-rata viabilitas spermatozoa sapi PO yang digunakan untuk penelitian adalah $91,39 \pm 2,38 \%$. Hal tersebut memiliki arti bahwa semen sapi PO yang digunakan dalam penelitian termasuk memenuhi syarat untuk digunakan. Ducha et al. (2013); Ismaya (2014) yang menyatakan bahwa semen yang akan diencerkan paling tidak minimal jumlah spermatozoa yang hidup 70\%.

Rata-rata persentase spermatozoa pada semen sapi PO yang belum mengalami kapasitasi secara berurutan yaitu $86,4 \pm 2,0 \%$. Rata-rata persentase spermatozoa yang sudah mengalami kapasitasi yaitu 9,4 $41,3 \%$. Dan rata-rata presentase spermatozoa yang telah mengalami

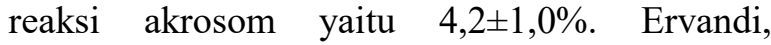
Susilawati, Wahyuningsih (2013) menyatakan bahwa semen sapi memiliki rata-rata 
spermatozoa yang belum mengalami kapasitasi sebesar 87,5\%, spermatozoa yang telah mengalami kapasitasi 9,4\% dan telah mengalami reaksi akrosom 3,0\%. Yeste, Briz, Pinart, Sancho, Garcia-Gil, Badia, Bassols, Pruneda, Bussalleu, Casas, Bonet (2008) menyatakan bahwa angka status akrosom semen sapi yaitu spermatozoa belum kapasitasi sekitar $85 \%$, spermatozoa terkapasitasi sekitar $10 \%$, dan spermatozoa telah mengalami reaksi akrosom sekitar 7\%.

\section{Spermatozoa Belum Kapasitasi}

Pemeriksaan status akrosom pada spermatozoa terdiri dari persentase spermatozoa belum kapasitasi, persentase spermatozoa terkapasitasi, dan persentase spermatozoa yang telah rekasi akrosom. Kondisi status akrosom spermatozoa sapi teridentifikasi salah satunya melalu perubahan peredaran kalsium pada sel spermatozoa yang bisa diamati menggunakan mikroskop epi-fluoresens dengan pewarnaan CTC. Hasil pengamatan spermatoza menggunakan mikroskop epi-fluoresens ditunjukkan dalam Gambar 1.

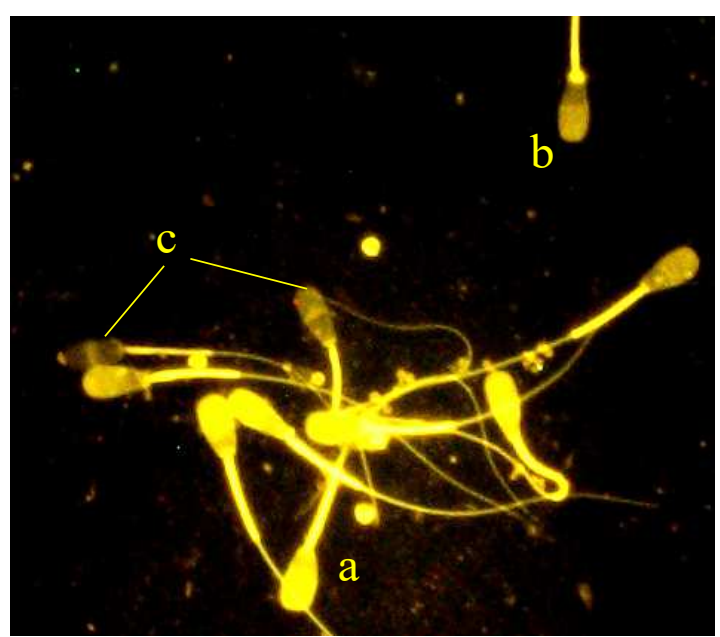

Gambar 1. Status Akrosom Spermatozoa Diamati Dengan Mikroskop Epi-fluorescence. a = belum kapasitasi, b: spermatozoa terkapasitasi, c: spermatozoa telah rekasi akrosom.

Adapun rata-rata dan simpang baku spermatozoa yang belum mengalami kapasitasi pada semen sapi PO baik sebelum pengenceran Tabel 2. Rata-rata spermatozoa belum kapasitasi maupun setelah pengenceran ditinjukkan pada Tabel 2.

Hasil analisis ragam dari persentase spermatozoa yang belum mengalami kapasitasi selama penyimpanan pada suhu dingin antar formulasi pengencer air kelapa yang berbeda ( $\mathrm{P} 1$, P2, dan P3) menunjukkan tidak terdapat perbedaan yang nyata $(\mathrm{P}>0,05)$ pada peyimpanan hari ke-1 dan kari ke-5. Meskipun demikian, persentase spermatozoa yang belum mengalami kapasitasi tergolong tinggi dari semua perlakuan hingga penyimpananhari ke-5 yaitu di atas $60 \%$. Spermatozoa dalam mempertahankan kondisi sehingga tidak mengalami kapasitasi sangat dipengaruhi oleh kolesterol membran. Moore et al. (2005) melaporkan bahwa kejadian penurunan yang signifikan pada kolesterol membran spermatozoa setelah dilakukan penurunan suhu yang sangat drastis. Kolesterol pada membran memiliki fungsi sebagai agen kapasitasi, jumlah dan distribusi kolesterol pada membran mengindikasikan tahapan-tahapan kapasitasi. Gualtieri (2010) menambahkan bahwa penipisan kolesterol membran spermatozoa menyebabkan peningkatan permeabilitas membran terhadap kalsium dan bikarbonat intraseluler yang pada akhirnya mengurangi persentase spermatozoa yang belum mengalami kapasitasi.

\section{Spermatozoa Terkapasitasi}

Kapasitasi adalah proses pelepasan bahanbahan pelapis membran spermatozoa secara bertahap, terutama pada bagian akrosom (Susilawati, 2011). Persentase spermatozoa yang telah mengalami kapasitasi merupakan salah satu parameter yang perlu diperhatikan untuk menentukan kualitas spermatozoa (Gualtieri, 2010). Rata-rata persentase spermatozoa yang telah mengalami kapasitasi pada kondisi segar, setelah penyimpanan hari ke-1 dan ke-5 ditinjukkan pada Tabel 3.

Hasil analisis ragam terhadap persentase spermatozoa yang telah mengalami kapasitasi selama penyimpanan pada suhu dingin antar formulasi pengencer air kelapa yang berbeda (P1, $\mathrm{P} 2$, dan P3) juga menunjukkan

\begin{tabular}{cccc}
\hline \multirow{2}{*}{$\mathbf{P}$} & \multicolumn{4}{c}{ Rata-rata spermatozoa belum kapasitasi (\%) \pm Simpang baku } \\
\cline { 2 - 4 } & Segar & H1 & H5 \\
\hline P1 & $86,02 \pm 2,63$ & $83,7 \pm 0,56$ & $64,85 \pm 0,70$ \\
P2 & $86,02 \pm 2,63$ & $83,9 \pm 1,23$ & $66,03 \pm 0,91$ \\
P3 & $86,02 \pm 2,63$ & $83,6 \pm 1,45$ & $65,87 \pm 0,22$ \\
\hline
\end{tabular}

Keterangan : $\mathrm{P}=$ Perlakuan, $\mathrm{H}=$ Hari penyimpanan. 
tidak terdapat perbedaan yang nyata $(\mathrm{P}>0,05)$ pada peyimpanan hari ke-1 dan kari ke-5. Meskipun tidak menunjukkan perbedaan yang nyata antar perlakuan namun berdasarkan hasil pada tabel diketahui bahwa jumlah spermatozoa yang mengalami kapasitasi sebakin hari semakin meningkat. Moore et al. (2005); Guyton dan Hall (2007) menjelaskan terjadinya penurunan yang signifikan pada kolesterol membran spermatozoa setelah pengenceran dan pendinginan. Kolesterol pada membran dapat berfungsi sebagai agen kapasitasi. Jumlah serta distribusi kolesterol membran spermatozoa mengindikasikan tahapantahapan kapasitasi. Penipisan kolesterol pada membran merupakan salah satu tahapan pertama dari kejadian kapasitasi yang ditandai oleh penurunan stabilitas membrane. Penipisan kolesterol membran dapat menyebabkan peningkatan kalsium intraseluler dan bikarbonat untuk mengaktifkan AC, menghasilkan cAMP, dan mengaktifkan PKA, selanjutnya protein kinase membuka kanal ion pada membran dan memodulasi peningkatan kalsium intraseluler.

\section{Spermatozoa Telah Reaksi Akrosom}

Rata-rata spermatozoa yang telah mengalami reaksi akrosom pada kondisi segar, setelah penyimpanan hari ke-1 dan ke-5 ditinjukkan pada Tabel 4.
Hasil analisis ragam persentase spermatozoa yang telah mrngalami reaksi akrosom antar perlakuan formulasi pengencer air kelapa yang berbeda (P1, P2, P3) yang berbeda pada bangsa sapi $\mathrm{PO}$ selama simpan dingin pada suhu $4-5^{\circ} \mathrm{C}$ menunjukkan tidak terdapat perbedaan yang nyata $(\mathrm{P}>0,05)$ pada peyimpanan hari ke-1 dan hari ke-5. Persentase keutuhan akrosom tersebut mengindikasikan bahwa tidak terdapat kerusakan spermatozoa yang dapat menurunkan kualitas kemampuan fertilisasi dari spermatozoa selama penyimpanan menggunakan pengencer air kelapa. Hernandez et al. (2012) menyatakan bahwa spermatozoa dikatakan kehilangan kemampuan fertilisasinya apabila kerusakan akrosom melebihi 50\%. Kerusakan akrosom spermatozoa tersebut berkaitan dengan fungsi membran sebagai pelindung akrosom spermatozoa. Guyton dan Hall (2007) menambahkan bahwa kolesterol merupakan salah satu komponen penyusun membran spermatozoa dan juga berfungsi memberikan sifat fluiditas pada membran sehingga tidak mudah rusak. Kandungan kolesterol tinggi pada membran akan membuat membran semakin bersifat lentur sebaliknya semakin rendah kandungan kolesterol pada membran akan menyebabkan spermatozoa semakin mudah mengalami kerusakan.

Tabel 3. Rata - rata spermatozoa terkapasitasi

\begin{tabular}{cccc}
\hline \multirow{2}{*}{$\mathrm{P}$} & \multicolumn{4}{c}{ Rata-rata spermatozoa belum kapasitasi $(\%) \pm$ Simpang baku } \\
\cline { 2 - 4 } & Segar & H1 & H5 \\
\hline P1 & $9,99 \pm 2,63$ & $10,71 \pm 0,56$ & $23,27 \pm 0,70$ \\
P2 & $9,99 \pm 2,63$ & $10,90 \pm 0,60$ & $21,87 \pm 0,35$ \\
P3 & $9,99 \pm 2,63$ & $10,79 \pm 0,31$ & $22,11 \pm 1,06$ \\
\hline
\end{tabular}

Keterangan : $\mathrm{P}=$ Perlakuan, $\mathrm{H}=$ Hari penyimpanan.

Tabel 4. Rata-rata spermatozoa telah reaksi akrosom

\begin{tabular}{cccc}
\hline \multirow{2}{*}{$\mathrm{P}$} & \multicolumn{3}{c}{ Rata-rata spermatozoa belum kapasitasi $(\%) \pm$ Simpang baku } \\
\cline { 2 - 4 } & Segar & H1 & H5 \\
\hline P1 & $3,99 \pm 1,36$ & $5,56 \pm 0,20$ & $11,80 \pm 0,40$ \\
P2 & $3,99 \pm 1,36$ & $5,21 \pm 0,64$ & $12,11 \pm 0,56$ \\
P3 & $3,99 \pm 1,36$ & $5,61 \pm 1,14$ & $12,02 \pm 0,84$ \\
\hline
\end{tabular}

Keterangan : $\mathrm{P}=$ Pelakuan, $\mathrm{H}=$ Hari penyimpanan.

\section{KESIMPULAN}

Tidak terdapat perbedaan pada persentase spermatozoa belum kapasitasi, terkapasitasi, dan telah rekasi akrosom antara perlakuan formulasi pengencer air kelapa yang berbeda (P1, P2, P3) selama peyimpana suhu $2-5^{\circ} \mathrm{C}$. Pengencer berbasis air kelapa mampu mempertahankan kualitas akrosom diatas $50 \%$ penyimpanan hari ke lima.

\section{UCAPAN TERIMA KASIH}

Kemenristek DIKTI yang telah memberikan dana penelitian dengan skema PUPTN dan Lembaga Pengelolah Dana Pendidikan (LPDP) melalui program BPI. Terima kasih juga kepada Loka Penelitian Sapi Potong Grati yang menyediakan tempat penelitian. 


\section{DAFTAR PUSTAKA}

Adnani Luh P.D.H, W. Bebas, \& M.K. Budiasa. 2012. Penambahan bovine serum albumin pada pengencer kuning telur terhadap motilitas dan daya hidup spermatozoa anjing. Indonesia Medicus Veterinus 1(4):519-529.

Audia R.P., M.A. Salim, N. Isnaini \& T. Susilawati. 2017. Pengaruh perbedaan kematangan air kelapa hijau sebagai bahan pengencer yang ditambah $10 \%$ kuning telur terhadap kualitas semen cair kambing Boer. Jurnal Ternak Tropika 18(1):58-68.

Ax R., M. Dally, B. Didion, R. Lenz, C. Love, D. Varner, Hafez, \& M. Bellin. 2008. Semen Evaluation. In Reproduction in Farm Animal ( $7^{\text {th }}$ edition). Edited by Hafez, E.S.E. Co. Director. Reproductive Health Kiawah Island. South Carolina. USA. pp 365-370.

Daramola J.O, E.O. Adekunle, O.E. Oke, O.M. Onagbesan, I.K. Oyewusi, \& J.A. Oyewusi. Effects of coconut (Cocos nucifera) water with or without egg-yolk on viability of cryopreserved buck spermatozoa. Anim. Reprod., Belo Horizonte 13(2):57-62.

Ducha N., T. Susilawati, Aulanni'am, \& S. Wahjuningsih. 2013. Motilitas dan viabilitas spermatozoa sapi Limousin selama penyimpanan pada refrigerator dalam pengencer CEP-2 dengan suplementasi kuning telur. Jurnal Kedokteran Hewan 7(1):5-8.

Ervandi M., T. Susilawati, \& S. Wahyuningsih. 2013. Effect of Different Diluents on the Quality of Sperm Sexing Cows With a Gradient Albumin (Egg White). Indonesian Journal of Animal and Veterinary 18 (3):177-184.

Garner D.L. \& E.S.E. Hafez. 2008. Spermatozoa and Seminal Plasma. In Reproduction in Farm Animals ( $7^{\text {th }}$ edition). Edited by E.S.E Hafez and B. Hafez. 2008. Lippincott \& Williams. Baltimore, Marryland. USA. pp 96-109.

Gualtieri R. 2010. Ability of Sulfated Glycoconjugates and Disulfide Reductants to Release Bovine Epididymal Sperm Bound to the Oviductal Epithelium In Vitro.Theriogenology 73:1037-1043.
Guyton A.C. \& J.E. Hall. 2007. Fisiologi Kedokteran. Edisi 11. Penerbit Buku Kedokteran EGC. Jakarta.

Hernandez P.J.E. R.F. Fernandez, S.J.L. Rodriguez, M.Y.G. Soto, J.E.H. Verona, \& R.A.D. Garcia. 2012. Post-thaw acrosomal viability and reaction in sperm obtained from equine epididymis tail. Rev Salud Anim. 34(2):84-88.

Ismaya. 2014. Bioteknologi Inseminasi Buatan pada Sapi dan Kerbau. Gadjah Mada University Press. Yogyakarta.

Moore A.I., E.L. Squires, \& J.K. Graham. 2005. Adding cholesterol to the stallion sperm plasma membrane improve cryosurvival. Cryobiology 51(3):241-249.

Morado S., V. Pereyra, E. Breininger, R. Sara, \& P. Cetica. (2015). Study of sperm evaluation parameters to estimate cryopreserved bovine semen fertility. Austin Journal of Veterinary Science \& Animal Husbandry 2(1):1005.

Muhammad D., T. Susilawati, \& S. Wahjuningsih. 2016. Pengaruh penggunaan CEP-2 dengan suplementasi kuning telur terhadap kualitas spermatozoa sapi FH (Frisian Holstein) kualitas rendah selama penyimpanan suhu $4-5^{\circ} \mathrm{C}$. Jurnal Ternak Tropika 17(1):66-76.

Mugiyati, M. A. Salin, N. Isnaini, \& T. Susilawati. 2017. Pengaruh air kelapa merah yang muda dan tua sebagai pengencer terhadap kualitas semen kambing Boer selama penyimpanan dingin. Jurnal Ternak Tropika 18(1):20-26.

Salim M.A., M.N. Ihsan, N. Isnaini, A.P.A. Yekti, \& T. Susilawati. 2018. Quality of Boer goad liquid semen on different coconut water diluent (Cocos nucifera) during cold storage. Asian Journal of Microbiology, Biotechnology \& Environmental Sciences 20:150-157.

Susilawati, T. 2011. Spermatology. Universitas Brawijaya (UB) Press. Malang.

Susilawati T., D. Ratnawati, N. Isnaini, Kuswati \& A. P. A. Yekti. 2018. Character of liquid semen motility in various diluents on Balinese cattle during cold storage. Asian Journal of Microbiology, Biotechnology \& Environmental Sciences 20(1):166-172. 
Vigliar R., V. L. Sdepanian, \& U. FagundesNeto. 2006. Biochemical profile of coconut water from coconut palms planted in an Inland Region. Jornal de Pediatria. 82(4):308-312.

Yeste, M., M. Briz, E. Pinart, S. Sancho, N. Garcia-Gil, E. Badia, J. Bassols, Pruneda, E. Bussalleu, I. Casas, \& S. Bonet. 2008. Hyaluronic acid delays boar sperm capacitation after 3 days of storage at 15 ${ }^{\circ} \mathrm{C}$. animal reproduction science 109:236250.

Yong J.W.H., L. Ge, Y.F. Ng \& S.N. Tan. 2009. The chemical composition and biological properties of coconut (Cocos nucifera L.) water. Molecules. 14: 5144-5164. 